\title{
E-COMMERCE DRIVERS AND BARRIERS AND THEIR IMPACT ON E-CUSTOMER LOYALTY IN SMALL AND MEDIUM-SIZED ENTERPRISES (SMES)
}

\author{
Ahmad Adnan AL-TIT (iD* \\ Department of Business and Economics, College of Business and Economics (CBE), Qassim University, \\ KSA. Al Malida, Buraidah, 15452, Qassim, Kingdom of Saudi Arabia
}

Received 22 November 2019; accepted 20 January 2020

\begin{abstract}
The aim of this paper is threefold: first to explore the factors that significantly and positively affect the adoption of e-commerce in SMEs; second, to determine the factors that hinder the adoption of e-commerce in these enterprises; and, finally, to investigate the impact of e-commerce-related factors on e-customer loyalty. Two samples were used for the purpose of the current study, the first of which comprised 163 managers of SMEs while the second consisted of 213 customers. Data were collected via electronic questionnaires sent to the study participants. The results identified 10 drivers of e-commerce, which are customer preferences, e-commerce perceived value, partner readiness, e-commerce cost, technical expertise, customer trust, employee knowledge and experience, top management support, perceived ease of use, and organizational culture, and 7 barriers to e-commerce adoption, which are employee technology knowledge, telecommunications, connectivity cost, technical expertise, technology cost, internet security, and legal barriers. Furthermore, the results highlighted that e-commerce ethics, information quality, customer trust, user interface quality, and customer satisfaction, respectively, are the main predictors of e-customer loyalty. Basically, organizations are called to adopt e-commerce to increase their customer loyalty. However, organizations should consider the drivers of and barriers to e-commerce adoption found in the current study.
\end{abstract}

Keywords: drivers of e-commerce adoption, barriers to e-commerce adoption, factors affecting e-customer loyalty, SMEs.

JEL Classification: M30, M31.

\section{Introduction}

The introduction of the Internet was a critical factor for the development of e-commerce. The term has been defined as completing business transactions via the Internet (Zaied, 2012). The clearest evidence of this is the increased volume of commerce around the globe among different countries using the Internet compared with business transactions conducted without the Internet. The Internet's role can be identified from the fact that it makes business transactions more efficient in terms of speed and accuracy (Sebora, Lee, \& Sukasame, 2009). Many potential benefits of e-commerce investment have been distinguished. For example, e-commerce provides companies with the ability to access new customers as well as global markets (Mullane, Peters, \& Bullington, 2001), enhances the success of entrepreneurship ventures (Senn, 2000), and helps companies to gain a competitive advantage (Ghobakhloo, AriasAranda, \& Benitez-Amado, 2011).
The study by Al-Tit, Omri, and Euchi (2019) determined four success factors of SMEs in Saudi Arabia: business support, management factors, capital availability, and individual factors. Based on the enlarged importance of e-commerce and its positive influence on numerous organizational outcomes and even on those of the country as a whole, it has attracted considerable attention from researchers. Examples of prior papers on e-commerce include, but are not limited to, e-commerce entrepreneurship success factors (Mullane et al., 2001; Sebora et al., 2009), enablers of and barriers to e-commerce (Kabanda \& Brown, 2015; Almousa, 2013; Lawrence \& Tar, 2010; Wong, 2003), e-commerce and entrepreneurship in agricultural markets (Mueller, 2001), e-commerce usage (Bharadwaj \& Soni, 2007), factors affecting e-commerce's diffusion (Gibbs, Kraemer, \& Dedrick, 2003), and the adoption of e-commerce by small and medium-sized enterprises (SMEs) (Wymer \& Regan, 2005). The study by

*Corresponding author. E-mails: aa.altit@qu.edu.sa,ahmteet@yahoo.com 
Raudeliūnienè et al. (2018) identified the success factors of women's leadership in e-commerce as personal competences, professional competences, social competences, management competences, and external factors. Another bundle of the literature includes e-commerce-related topics such as customer loyalty in the context of e-commerce (Srinivasan, Anderson, \& Ponnavolu, 2002), emotional support, informational support, trust, social commerce constructs, and social commerce intention (Al-Tit et al., 2020). The findings reported in the related works have included a number of factors, such as entrepreneurs' achievement orientation, locus of control, and electronic service quality (Sebora et al., 2009). To encourage e-commerce success, authors (e.g., Agag, 2019; Arshad et al., 2018; Awa, Ojiabo, \& Emecheta, 2015a; Awa, Awara, \& Lebari, 2015b; Rahayu \& Day, 2015; Chuang et al., 2007; Corbitt, Thanasankit, \& Yi, 2003; Eid, 2011; Hussein et al., 2019) have underlined many factors that improve e-commerce adoption and application. Examples of these factors include the availability of financial resources, top management support, involvement in global production networks, technical expertise, and e-commerce's perceived value and compatibility as well as the organizational culture. Other factors are related to the customers, like their satisfaction (Davidavičienè, Davidavičius, \& Kaušinis, 2019), trust, and support. Technology factors, on the other hand, include technology vendors' support, perceived ease of use, and cost in addition to some factors like partner readiness and employee knowledge and experience.

In contrast, authors have identified numerous barriers to e-commerce adoption, like factors related to infrastructure and external institutional support and socio-cultural and socio-economic factors (Lawrence \& Tar, 2010). Some of these barriers cited by authors (e.g., Dwivedi, Lal, \& Williams, 2009; Hallikainen \& Laukkanen, 2018; Scupola, 2009; Van Huy et al., 2012; Zaied, 2012; Almousa, 2013; Feindt, Jeffcoate, \& Chappell, 2002; Rahayu \& Day, 2015) embrace the internet connectivity cost, price sensitivity, brand image, convenience and security, technical expertise, management and employee technology knowledge, technology and e-commerce applications' cost, customer readiness, payment systems, and legal barriers. To examine the outcomes of e-commerce adoption, such as organizational performance and customer loyalty, authors (e.g., Eid, 2011; Hua et al., 2019; Srinivasan et al., 2002) have investigated the effect of some variables, like e-commerce characteristics, on e-customer loyalty. Following these studies, the current study tries to detect the drivers of, barriers to, and positive outcomes of e-commerce adoption.

\section{Literature review and hypothesis development}

\subsection{Factors affecting e-commerce adoption}

E-commerce has been defined as an Internet application used for business transactions and business relationship maintenance (Awa et al., 2015b). The adoption of e-commerce was defined by Ghobakhloo et al. (2011) as the utilization of information and communication technologies and related applications to support the management, decision-making processes, and business processes. Sabaityte et al. (2019) determined the most importance internet marketing communication elements in the purchase phase of the e-consumer journey cycle using the mathematical decision tree approach. Al-Tit and Nakhleh (2014) explained the role of e-marketing in the development of Internet user attitudes. Arshad et al. (2018) argued that an enterprise that achieves an interactive status of e-commerce can be regarded as successful in e-commerce adoption. E-commerce adoption has been explored by numerous researchers. The most commonly cited framework of e-commerce adoption is the one introduced by Tornatzky and Fleischer (1990), which is the technology-organization-environment framework. According to Awa et al. (2015a, 2015b), and Rahayu and Day (2015), technological factors refer to internal and external factors, such as technical compatibility, and observability. Organizational factors are factors such as organizational culture, centralization, and human resource quality. Finally, environmental factors include factors concerned with competitiveness, partners' readiness, government support, and socio-cultural factors.

Gibbs et al. (2003) differentiated between business-tobusiness (B2B) e-commerce and business-to-consumer (B2C) e-commerce and indicated that $\mathrm{B} 2 \mathrm{~B}$ e-commerce is affected by global factors while B2C e-commerce is influenced by local factors. In their study on the adoption of e-commerce applications in SMEs in Spain, Ghobakhloo et al. (2011) identified seven factors that affect the adoption of e-commerce, which are the CEO's innovativeness, buyer/supplier pressure, technology vendors' support, information intensity, competition, e-commerce's perceived relative advantage, and perceived compatibility. Similar to other studies, not all the proposed factors were found to exert effects on e-commerce adoption and application. For example, the technology cost and business size were found by the same authors to have no effect on e-commerce adoption. Daniel et al. (2002) explored the adoption of e-commerce in SMEs in the UK and identified four stages in which enterprises are engaged to adopt e-commerce: first, developing e-commerce services, followed by using electronic mail to communicate with customers, using websites and developing online ordering, and finally starting online transactions. The authors indicated that the internal factors, such as the employee turnover, number of employees, and age of the company, have no effect on the adoption of e-commerce.

Furthermore, nine factors that support the adoption of e-commerce by SMEs in Vietnam were identified by Van Huy et al. (2012): government support, industry support, enterprise resources, enterprise size, managers' attitudes towards innovation, competition intensity, employees' knowledge of e-commerce, customer and supplier attitudes, and innovation compatibility. Arshad et al. (2018), in their study on the adoption of e-commerce by 
SMEs in Malaysia, found that perceived ease of use of ecommerce applications, e-commerce relative advantage, ecommerce perceived compatibility, e-commerce security, and top management support had significant effects on the adoption of e-commerce. On the basis of responses collected from supply chain managers from Jordan, Alsaad, Mohamad, and Ismail (2018) tested an e-commerce adoption model consisting of four factors, which were perceived as desirability, top management support, organizational readiness, and competitive pressure, and found that all these factors except organizational readiness had significant effects on the intention to adopt business-tobusiness e-commerce. Gathering qualitative data on the adoption of e-commerce by SMEs in Nigeria, Ekanem and Abiade (2018) found that internet access, an enhanced banking sector, and an increase in mobile devices as well as changes in customers' lifestyle were the key factors that enabled SMEs to adopt e-commerce. The perceived usefulness of e-commerce was approved by Hussein et al. (2019) as a significant mediator in the relationship between ecommerce's relative advantage and information intensity and its continued use.

Table 1. Factors that affect e-commerce adoption

\begin{tabular}{|c|c|c|}
\hline \multicolumn{2}{|c|}{ E-commerce adoption drivers } & Scholars \\
\hline $\begin{array}{l}\text { Organi- } \\
\text { zational } \\
\text { factors }\end{array}$ & $\begin{array}{l}\text { Financial resources } \\
\text { Top management support } \\
\text { Involvement in global } \\
\text { production networks } \\
\text { Potential profitability of } \\
\text { e-commerce } \\
\text { Technical expertise } \\
\text { CEO's innovativeness } \\
\text { E-commerce perceived } \\
\text { value } \\
\text { E-commerce perceived } \\
\text { compatibility } \\
\text { Organizational culture }\end{array}$ & \multirow{5}{*}{$\begin{array}{l}\text { Agag (2019), } \\
\text { Alsaad et al. } \\
\text { (2018), Al-Tit } \\
\text { and Nakhleh } \\
\text { (2014), Arshad } \\
\text { et al. (2018), Awa } \\
\text { et al. (2015a, } \\
\text { 2015b), Chuang } \\
\text { et al. (2007), } \\
\text { Corbitt et al. } \\
\text { (2003), Daniel } \\
\text { et al. (2002), } \\
\text { Dwivedi et al. } \\
\text { (2009), Eid (2011), } \\
\text { Ekanem and } \\
\text { Abiade (2018), } \\
\text { Gefen (2000), } \\
\text { Ghobakhloo et al. } \\
\text { (2011), Gibbs } \\
\text { et al. (2003), } \\
\text { Hallikainen } \\
\text { and Laukkanen } \\
\text { (2018), Hussein } \\
\text { et al. (2019), } \\
\text { Raudeliūnienè } \\
\text { et al. (2018), } \\
\text { Scupola (2009), } \\
\text { Van Huy et al. } \\
\text { (2012), Wymer } \\
\text { and Regan (2005), } \\
\text { Al-Tit et al. } \\
\text { (2020). }\end{array}$} \\
\hline $\begin{array}{l}\text { Customer } \\
\text { factors }\end{array}$ & $\begin{array}{l}\text { Customer preferences } \\
\text { Trust } \\
\text { Customer support }\end{array}$ & \\
\hline $\begin{array}{l}\text { Technology } \\
\text { factors }\end{array}$ & $\begin{array}{l}\text { Information infrastructure } \\
\text { Cost } \\
\text { Reliability } \\
\text { Technology vendors' } \\
\text { support } \\
\text { Technology perceived } \\
\text { usefulness } \\
\text { Perceived ease of use }\end{array}$ & \\
\hline $\begin{array}{l}\text { Environ- } \\
\text { mental } \\
\text { factors }\end{array}$ & $\begin{array}{l}\text { Formal rules and } \\
\text { regulations } \\
\text { Partner readiness } \\
\text { Global and local } \\
\text { competition } \\
\text { Socio-cultural factors }\end{array}$ & \\
\hline $\begin{array}{l}\text { Knowledge } \\
\text { factors }\end{array}$ & $\begin{array}{l}\text { Innovativeness } \\
\text { Employee knowledge and } \\
\text { experience } \\
\text { Information intensity } \\
\text { Need for e-commerce } \\
\text { adoption }\end{array}$ & \\
\hline
\end{tabular}

For the current study, the factors of the technological, organizational, and environmental (TOE) model developed by Tornatzky and Fleischer, as cited in Hussein et al. (2019), were adopted as the drivers of e-commerce in addition to customer and knowledge factors. That is, top management support, technical expertise, perceived value of e-commerce, organizational culture, customer trust, customer preferences, e-commerce perceived ease of use, e-commerce cost, partner readiness, and employee knowledge were used as exogenous constructs. Therefore, the following hypotheses were developed:

H1: Top management support exerts a significant effect on e-commerce adoption.

H2: Technical expertise exerts a significant effect on e-commerce adoption.

H3: The perceived value of e-commerce exerts a significant effect on e-commerce adoption.

H4: The organizational culture exerts a significant effect on e-commerce adoption.

H5: Customer trust exerts a significant effect on e-commerce adoption.

H6: Customer preferences exert a significant effect on e-commerce adoption.

H7: E-commerce's perceived ease of use exerts a significant effect on e-commerce adoption.

H8: E-commerce's cost exerts a significant effect on e-commerce adoption.

H9: Partner readiness exerts a significant effect on e-commerce adoption.

H10: Employee knowledge exerts a significant effect on e-commerce adoption.

\subsection{Barriers to e-commerce adoption}

Despite the advantageous usage of e-commerce to achieve positive organizational outcomes, researchers have determined that the adoption and application of e-commerce can be deactivated due to several barriers, such as a lack of adequate infrastructure and the absence of national information and communication technology strategies (Lawrence \& Tar, 2010). Regarding the barriers to e-commerce adoption among SMEs in Egypt, Zaied (2012) found that technical and legal barriers, a lack of internet security, and limited use of internet banking and web portals by those enterprises are the most pivotal barriers that hinder the adoption of e-commerce adoption. In fact, the author identified about thirty barriers to e-commerce adoption concerning government regulations and policy, competitiveness, cultural differences, and innovativeness as well as a lack of e-commerce advantages, a lack of financial resources, technical expertise, e-commerce infrastructure, and internet security. Scupola (2009) conducted a study on Denmark and Australia and underlined some e-commerce barriers like employees' low level of information technology, absence of innovativeness and managerial time, visible evaluation of e-commerce returns, and cost. Van Huy et al. (2012) identified two factors that have negative effects on e-commerce adoption, which were innovation complexity and e-commerce perceived risk. 
Table 2. Barriers affecting e-commerce adoption

\begin{tabular}{|c|c|c|}
\hline \multicolumn{2}{|c|}{ E-commerce adoption barriers } & Scholars \\
\hline $\begin{array}{l}\text { Organi- } \\
\text { zational } \\
\text { barriers }\end{array}$ & $\begin{array}{l}\text { Employee technology } \\
\text { knowledge } \\
\text { Lack of CEO's } \\
\text { innovativeness } \\
\text { Lack of managerial time } \\
\text { Managerial e-commerce } \\
\text { experience }\end{array}$ & \multirow{5}{*}{$\begin{array}{l}\text { Agag (2019), } \\
\text { Chuang et al. (2007), } \\
\text { Corbitt et al. (2003), } \\
\text { Dwivedi et al. } \\
\text { (2009), Eid (2011), } \\
\text { Ghobakhloo et al. } \\
\text { (2011), Gibbs et al. } \\
\text { (2003), Hallikainen } \\
\text { and Laukkanen } \\
\text { (2018), Lawrence } \\
\text { and Tar (2010), } \\
\text { Scupola (2009), Van } \\
\text { Huy et al. (2012), } \\
\text { Zaied (2012), } \\
\text { Almousa (2013). }\end{array}$} \\
\hline $\begin{array}{l}\text { Infra- } \\
\text { structure } \\
\text { barriers }\end{array}$ & $\begin{array}{l}\text { Telecommunications } \\
\text { Connectivity cost } \\
\text { Technical expertise }\end{array}$ & \\
\hline $\begin{array}{l}\text { Technology } \\
\text { barriers }\end{array}$ & $\begin{array}{l}\text { Technology cost } \\
\text { Internet security } \\
\text { Limited usage/ } \\
\text { bandwidth }\end{array}$ & \\
\hline $\begin{array}{l}\text { External } \\
\text { barriers } \\
\text { Socio- } \\
\text { cultural } \\
\text { barriers }\end{array}$ & $\begin{array}{l}\text { Legal barriers } \\
\text { Lack of customer } \\
\text { readiness } \\
\text { Lack of transactional } \\
\text { trust } \\
\text { Social status } \\
\text { Language }\end{array}$ & \\
\hline $\begin{array}{l}\text { Socio- } \\
\text { economic } \\
\text { barriers }\end{array}$ & $\begin{array}{l}\text { Educational system } \\
\text { Economic conditions } \\
\text { Payment system }\end{array}$ & \\
\hline
\end{tabular}

According to Chuang et al. (2007), there is a significant impact of managerial experience on the adoption of e-commerce by SMEs. In the current study, managerial experience was categorized as an organizational barrier. Examining the main global, policy, and environmental factors based on systematic comparisons of case studies selected from 10 countries, specifically Brazil, China, Denmark, Germany, Japan, France, Mexico, Singapore, Taiwan, and the United States, Gibbs et al. (2003) found that trade and communication liberalization had the largest impact on e-commerce diffusion. Other factors related to e-commerce were legislation and customer trust.

To investigate the effect of 10 barriers to e-commerce adoption out of those cited in Table 2 using our data, the following hypotheses were developed:

H11:Employee technology knowledge exerts a negative effect on e-commerce adoption.

H12: The CEO's innovativeness exerts a negative effect on e-commerce adoption.

H13:Managerial time exerts a negative effect on e-commerce adoption.

H14:Managerial e-commerce experience exerts a negative effect on e-commerce adoption.

H15:Telecommunications exert a negative effect on e-commerce adoption.

H16: The connectivity cost exerts a negative effect on e-commerce adoption.

H17:Technical expertise exerts a negative effect on e-commerce adoption.

H18: The technology cost exerts a negative effect on e-commerce adoption.
H19:Internet security exerts a negative effect on e-commerce adoption.

H20: Legal barriers exert a negative effect on e-commerce adoption.

\subsection{Effects of e-commerce adoption and application}

The positive effects of e-commerce adoption are numerous. Examples include a positive economic impact (Wong, 2003). According to Srinivasan et al. (2002), characteristics such as customization, contact interactivity, cultivation, care, community, choice, and character have significant effects on customer e-loyalty. A study by Eid (2011) from Saudi Arabia found that e-commerce customers' loyalty is strongly affected by their satisfaction and weakly affected by customer trust. The author examined the following factors: information quality, user interface quality, perceived security, and perceived privacy. The results indicated that the culture of Saudi Arabia, information, and user interface quality of e-commerce services are significant drivers of e-commerce satisfaction and loyalty and that customer satisfaction is a significant predictor of customer loyalty. In Lithuania, the study by Davidavičiene, Davidavičius, and Kaušinis (2019) explained the importance of consumers' perception and understanding of service quality and e-logistic services in e-commerce satisfaction.

Specifically, some authors have investigated particular factors, such as e-commerce ethics, of the customer-related factors. Agag (2019) explored the effect of e-commerce ethics on customers' repurchase intention and loyalty using data from SMEs in Egypt and showed that customers' perceptions of e-commerce providers' ethics had a significant impact on their repurchase intention and loyalty. The author measured e-commerce providers' ethics through communication, security, non-deception, reliability,

Table 3. Effects of e-commerce on other variables

\begin{tabular}{|l|l|l|l|}
\hline \multicolumn{1}{|c|}{$\begin{array}{c}\text { Independent } \\
\text { variable }\end{array}$} & $\begin{array}{l}\text { Mediating/ } \\
\text { moderating } \\
\text { variable }\end{array}$ & \multicolumn{1}{|c|}{$\begin{array}{c}\text { Dependent } \\
\text { variable }\end{array}$} & Scholars \\
\hline $\begin{array}{l}\text { E-commerce } \\
\text { characteristics: } \\
\text { customization, } \\
\text { contact } \\
\text { interactivity, } \\
\text { cultivation, care, } \\
\text { community, } \\
\text { choice, and } \\
\text { character }\end{array}$ & - & $\begin{array}{l}\text { Customer } \\
\text { e-loyalty }\end{array}$ & $\begin{array}{l}\text { Srinivasan } \\
\text { et al. } \\
(2002)\end{array}$ \\
\hline $\begin{array}{l}\text { E-commerce } \\
\text { service } \\
\text { characteristics }\end{array}$ & $\begin{array}{l}\text { Customer } \\
\text { satisfaction } \\
\text { Customer } \\
\text { trust }\end{array}$ & $\begin{array}{l}\text { E-customer } \\
\text { loyalty }\end{array}$ & $\begin{array}{l}\text { Eid } \\
(2011)\end{array}$ \\
\hline $\begin{array}{l}\text { Loyalty } \\
\text { programmes }\end{array}$ & $\begin{array}{l}\text { E-commerce } \\
\text { initiatives }\end{array}$ & $\begin{array}{l}\text { Organizational } \\
\text { performance }\end{array}$ & $\begin{array}{l}\text { Hua et al. } \\
(2019)\end{array}$ \\
\hline $\begin{array}{l}\text { E-commerce } \\
\text { ethics }\end{array}$ & $\begin{array}{l}\text { Relationship } \\
\text { quality } \\
\text { (trust and } \\
\text { satisfaction) }\end{array}$ & $\begin{array}{l}\text { Customer } \\
\text { repurchase } \\
\text { intention and } \\
\text { loyalty }\end{array}$ & $\begin{array}{l}\text { Agag } \\
\text { (2019) }\end{array}$ \\
\hline
\end{tabular}


shared value, privacy, and service recovery. Other authors, on the other hand (e.g., Hua et al., 2019), have indicated that the performance of organizations, for example hotels, can be enhanced through the integration of e-commerce initiatives and loyalty programmes.

On the basis on the results in Table 3, through which a potential effect of e-commerce adoption was established using the current data on customer e-loyalty, the following hypotheses are proposed:

H21: E-commerce user interface quality exerts a significant effect on e-customer loyalty.

H22: E-commerce information quality exerts a significant effect on e-customer loyalty.

H23: E-commerce customer satisfaction exerts a significant effect on e-customer loyalty.

H24: E-commerce customer trust exerts a significant effect on e-customer loyalty.

H25: E-commerce ethics exert a significant effect on e-customer loyalty.

\section{Methodology}

\subsection{Study sample}

In accordance with the objectives of this study, which seeks to explore the drivers and barriers affecting the adoption of e-commerce as well as to investigate the impact of ecommerce adoption on e-commerce customer loyalty, the study used separate samples. The first one comprised 163 managers randomly selected from SMEs in different industries, while the second one included customers of these SMEs. They were chosen using the convenience sampling technique, obtaining a total of 213 customers.

\subsection{Study models}

The conceptual model 1 of the current study, as shown in Figure 1, consists of 10 exogenous constructs and 1 endogenous construct, which is the adoption of e-commerce. The exogenous constructs represent the factors affecting SMEs' adoption of e-commerce. The model contains 10 hypotheses on the impact of factors affecting the adoption of e-commerce. Figure 2 displays the second conceptual model of this study. It shows 10 hypothesized influences of e-commerce barriers on e-commerce adoption. Figure 3 illustrates the third conceptual model of the study. The model postulates the influence of $5 \mathrm{e}$-commerce constructs on e-commerce loyalty.

\subsection{Measures}

Factors that affect the adoption of e-commerce, represented by organizational factors, customer factors, technology factors, knowledge factors, and environmental factors, were measured using 40 items. As illustrated in Figure 1, there were 10 sub-factors, each of which was assessed by 4 items (Corbitt et al., 2003; Gefen, 2000; Ghobakhloo et al., 2011; Gibbs et al., 2003; Wymer \& Regan, 2005).

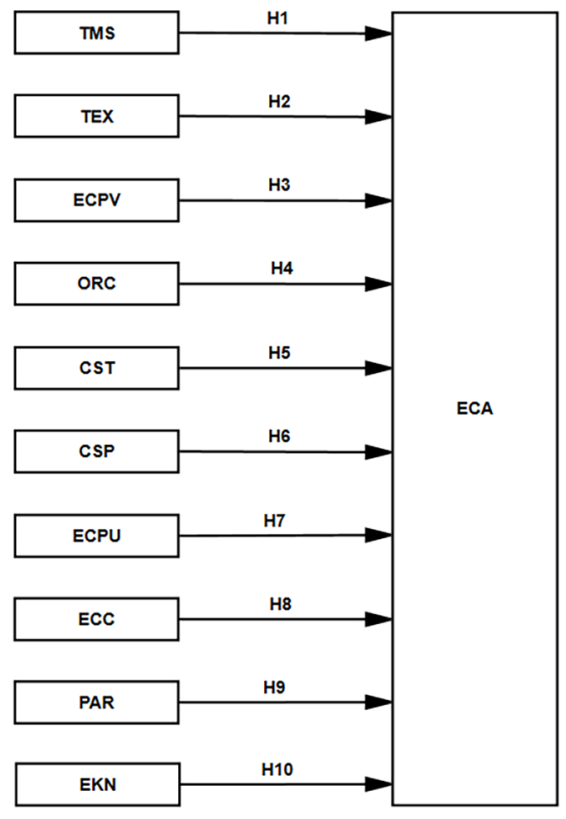

Figure 1. Conceptual model 1

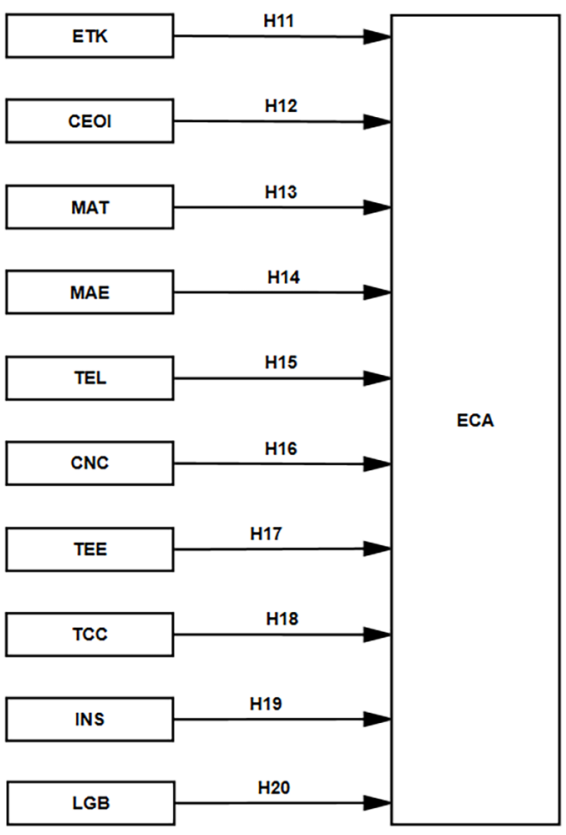

Figure 2. Conceptual model 2

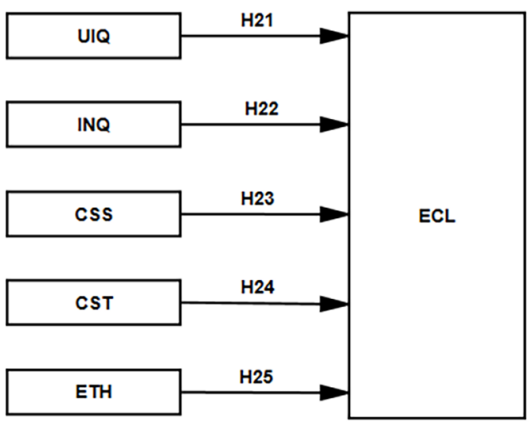

Figure 3. Conceptual model 3 
E-commerce adoption was measured on the basis of the related literature using factors concerning the same construct. Most studies that have examined e-commerce have mixed measures of e-commerce; hence, the current study separates the items used to measure the independent variables and the dependent variable. In this study, e-commerce is the dependent variable. According to Ghobakhloo et al. (2011), e-commerce is the utilization of information and communication technologies and related applications to support management, decisionmaking processes, and business processes. Consequently, the items used to measure e-commerce adoption in this study covered issues associated with the adoption of ecommerce applications to assist in the decision-making, business, and managerial processes. Four items were used to evaluate e-commerce adoption.

The barriers that affect e-commerce adoption were measured as organizational barriers, infrastructure barriers, technology barriers, socio-cultural barriers, and socio-economic barriers. As shown in Figure 2, 10 barriers were used. Examples of these barriers include employee technology knowledge, technology costs, and legal barriers. A total of 30 items were used to assess the ecommerce barriers.

Furthermore, the e-commerce user interface and information quality were evaluated following Eid (2011), while customer satisfaction and customer trust were measured following Kassim and Abdullah (2010). Finally, items of e-commerce ethics were adapted from Agag (2019). Overall, these accounted for 15 items. Following Srinivasan et al. (2002), e-customer loyalty was measured using customization and contact interactivity. Customization was measured through 4 items related to the match between customer needs and business recommendations, business promotions, product orders, and e-commerce service customization, while contact interactivity was assessed through 3 items concerning product comparisons, product views, and product location. In total, 7 items were used to appraise e-customer loyalty.

\section{Results}

\subsection{E-commerce drivers}

The results shown in Table 4 describe the rotated component matrix of e-commerce drivers, which was extracted using IBM SPSS 24.0 and AMOS 22.0.

The results in Table 4 confirm that the items used to assess the drivers of e-commerce (1-40) loaded on 10 factors, except item no. 27, which was removed due to cross-loading. The scree plot of these factors can be seen in Figure 4. Following Al-Tit (2016) and Rahman et al. (2016), the average variance extracted (AVE) was employed to assess the convergent validity. It was noted that the scale used in this study is valid, since all the values of the AVE were acceptable, that is, greater than 0.50. The discriminant validity, on the other hand, was rated using the square root of the AVE ( $\sqrt{A V E})$. It was also confirmed.
Table 4. Rotated component matrix of e-commerce drivers

\begin{tabular}{|c|c|c|c|c|c|}
\hline $\begin{array}{l}\text { Factors and } \\
\text { indicators }\end{array}$ & Items & SFL & AVE & $\sqrt{ } \mathrm{AVE}$ & $\omega$ \\
\hline \multirow{4}{*}{$\begin{array}{l}\text { Top } \\
\text { management } \\
\text { support }\end{array}$} & 01 & 0.980 & \multirow{4}{*}{0.962} & \multirow{4}{*}{0.981} & \multirow{4}{*}{0.992} \\
\hline & 02 & 0.984 & & & \\
\hline & 03 & 0.973 & & & \\
\hline & 04 & 0.986 & & & \\
\hline \multirow{4}{*}{$\begin{array}{l}\text { Technical } \\
\text { expertise }\end{array}$} & 05 & 0.858 & \multirow{4}{*}{0.716} & \multirow{4}{*}{0.846} & \multirow{4}{*}{0.909} \\
\hline & 06 & 0.884 & & & \\
\hline & 07 & 0.792 & & & \\
\hline & 08 & 0.847 & & & \\
\hline \multirow{4}{*}{$\begin{array}{l}\text { E-commerce } \\
\text { perceived } \\
\text { value }\end{array}$} & 09 & 0.859 & \multirow{4}{*}{0.761} & \multirow{4}{*}{0.872} & \multirow{4}{*}{0.927} \\
\hline & 10 & 0.892 & & & \\
\hline & 11 & 0.873 & & & \\
\hline & 12 & 0.866 & & & \\
\hline \multirow{4}{*}{$\begin{array}{l}\text { Organi- } \\
\text { zational } \\
\text { culture }\end{array}$} & 13 & 0.912 & \multirow{4}{*}{0.784} & \multirow{4}{*}{0.885} & \multirow{4}{*}{0.936} \\
\hline & 14 & 0.884 & & & \\
\hline & 15 & 0.880 & & & \\
\hline & 16 & 0.866 & & & \\
\hline \multirow{4}{*}{$\begin{array}{l}\text { Customer } \\
\text { trust }\end{array}$} & 17 & 0.926 & \multirow{4}{*}{0.904} & \multirow{4}{*}{0.950} & \multirow{4}{*}{0.974} \\
\hline & 18 & 0.964 & & & \\
\hline & 19 & 0.982 & & & \\
\hline & 20 & 0.929 & & & \\
\hline \multirow{4}{*}{$\begin{array}{l}\text { Customer } \\
\text { preferences }\end{array}$} & 21 & 0.943 & \multirow{4}{*}{0.865} & \multirow{4}{*}{0.930} & \multirow{4}{*}{0.962} \\
\hline & 22 & 0.959 & & & \\
\hline & 23 & 0.932 & & & \\
\hline & 24 & 0.884 & & & \\
\hline \multirow{4}{*}{$\begin{array}{l}\text { Perceived } \\
\text { ease of use }\end{array}$} & 25 & 0.919 & \multirow{4}{*}{0.805} & & \\
\hline & 26 & 0.918 & & 7007 & م0 \\
\hline & 27 & Removed & & 0.891 & 0.820 \\
\hline & 28 & 0.853 & & & \\
\hline & 29 & 0.982 & & & \\
\hline E-commerce & 30 & 0.970 & 0000 & 0018 & 0072 \\
\hline cost & 31 & 0.943 & 0.900 & 0.948 & 0.973 \\
\hline & 32 & 0.898 & & & \\
\hline & 33 & 0.950 & & & \\
\hline Partner & 34 & 0.953 & $00 \Omega$ & $0 \Omega$ & קחת \\
\hline readiness & 35 & 0.983 & 0.930 & 0.964 & 0.982 \\
\hline & 36 & 0.971 & & & \\
\hline & 37 & 0.891 & & & \\
\hline $\begin{array}{l}\text { Empioyee } \\
\text { knowledge }\end{array}$ & 38 & 0.953 & בת & & \\
\hline and & 39 & 0.955 & 0.852 & 0.923 & 0.958 \\
\hline experience & 40 & 0.892 & & & \\
\hline
\end{tabular}

Reliability, in the current study, was determined on the basis of McDonald's omega coefficient ( $\omega$ ). An important assumption of Cronbach's alpha coefficient is that this test is essentially tau equivalent (Al-Tit, 2016; Green \& 


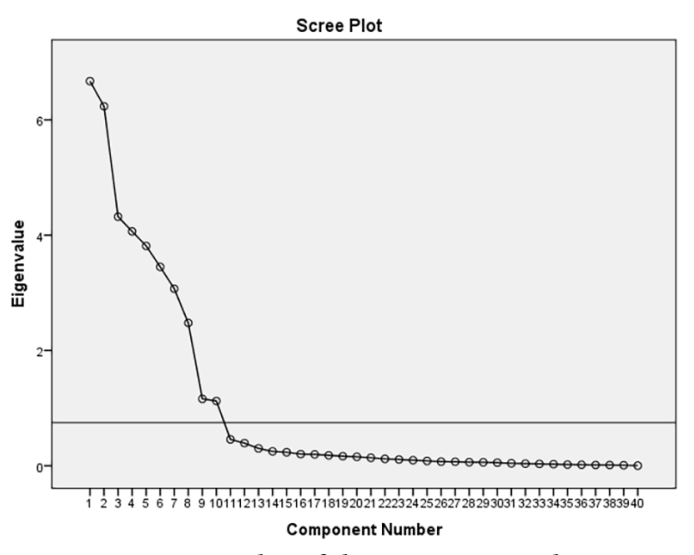

Figure 4. Scree plot of the e-commerce drivers

Yang, 2015). In the case of violation of this assumption, Cronbach's alpha cannot be used to estimate reliability. According to Dunn, Baguley, and Brunsden (2014), the alpha coefficient is based on hard assumptions that can easily be met. In the current study, the assumption of the alpha coefficient, using IBM SPSS 24.0 and AMOS 22.0, was not achieved; therefore, an alternative test was used, which was McDonald's omega coefficient $(\omega)$. It has been recommended in such cases by numerous authors (e.g., McNeish, 2018; Teo \& Fan, 2013). Returning to Table 1, the results indicate that the scale used to measure e-commerce drivers was reliable, since all the McDonald's omega coefficients were higher than 0.70 .

\subsection{E-commerce barriers}

The results concerning the e-commerce barriers in Table 5 highlight that the items used to appraise the e-commerce barriers loaded on 10 factors. The same result was confirmed by the scree plot of those factors, as shown in Figure 5. The table shows that the factor loadings of those items ranged from 0.775 to 0.957 . Appropriately, the AVE values were greater than 0.50 , establishing an acceptable degree of convergent validity. The discriminant validity was also approved using the values of the square root of the AVE ( $\mathrm{AVE})$.

Furthermore, the reliability, as previously highlighted, was judged based on McDonald's omega coefficients, and these coefficients were greater than 0.70 (Osman et al., 2012). The omega coefficients ranged from 0.773 to 0.969 . McDonald's omega coefficient has been used by several scholars (e.g., Maydeu-Olivares et al., 2009; Osman et al., 2012). In agreement with the results reported in Table 5, Figure 5 displays the scree plot of e-commerce barriers.

\subsection{E-commerce adoption}

For the items of e-commerce adoption, the results in $\mathrm{Ta}$ ble 6 demonstrate that 1 factor was extracted with factor loadings ranging from 0.675 to 0.945 . The validity, as measured by the AVE and $\sqrt{ }$ AVE, was supported. In addition, the reliability, as measured by McDonald's omega coefficient, was supported.
Table 5. Rotated component matrix of e-commerce barriers

\begin{tabular}{|c|c|c|c|c|c|}
\hline $\begin{array}{l}\text { Factors and } \\
\text { indicators }\end{array}$ & Items & $\begin{array}{l}\text { Factors } \\
\text { loading }\end{array}$ & AVE & $\sqrt{ }$ AVE & $\omega$ \\
\hline \multirow{3}{*}{$\begin{array}{l}\text { Employee } \\
\text { technology } \\
\text { knowledge }\end{array}$} & 41 & 0.950 & \multirow{3}{*}{0.892} & \multirow{3}{*}{0.944} & \multirow{3}{*}{0.858} \\
\hline & 42 & 0.959 & & & \\
\hline & 43 & 0.924 & & & \\
\hline \multirow{3}{*}{$\begin{array}{l}\text { Lack of CEO's } \\
\text { innovativeness }\end{array}$} & 44 & 0.881 & \multirow{3}{*}{0.711} & \multirow{3}{*}{0.843} & \multirow{3}{*}{0.773} \\
\hline & 45 & 0.869 & & & \\
\hline & 46 & 0.775 & & & \\
\hline \multirow{3}{*}{$\begin{array}{l}\text { Lack of } \\
\text { managerial time }\end{array}$} & 47 & 0.918 & \multirow{3}{*}{0.853} & \multirow{3}{*}{0.923} & \multirow{3}{*}{0.842} \\
\hline & 48 & 0.928 & & & \\
\hline & 49 & 0.925 & & & \\
\hline \multirow{3}{*}{$\begin{array}{l}\text { Managerial } \\
\text { e-commerce } \\
\text { experience }\end{array}$} & 50 & 0.900 & \multirow{3}{*}{0.807} & \multirow{3}{*}{0.898} & \multirow{3}{*}{0.926} \\
\hline & 51 & 0.902 & & & \\
\hline & 52 & 0.893 & & & \\
\hline \multirow{3}{*}{$\begin{array}{l}\text { Telecommu- } \\
\text { nications }\end{array}$} & 53 & 0.935 & \multirow{3}{*}{0.856} & \multirow{3}{*}{0.925} & \multirow{3}{*}{0.947} \\
\hline & 54 & 0.930 & & & \\
\hline & 55 & 0.910 & & & \\
\hline \multirow{3}{*}{$\begin{array}{l}\text { Connectivity } \\
\text { cost }\end{array}$} & 56 & 0.933 & \multirow{3}{*}{0.859} & \multirow{3}{*}{0.926} & \multirow{3}{*}{0.948} \\
\hline & 57 & 0.929 & & & \\
\hline & 58 & 0.919 & & & \\
\hline \multirow{3}{*}{$\begin{array}{l}\text { Technical } \\
\text { expertise }\end{array}$} & 59 & 0.912 & \multirow{3}{*}{0.816} & \multirow{3}{*}{0.903} & \multirow{3}{*}{0.93} \\
\hline & 60 & 0.914 & & & \\
\hline & 61 & 0.884 & & & \\
\hline \multirow{3}{*}{ Technology cost } & 62 & 0.950 & \multirow{3}{*}{0.881} & \multirow{3}{*}{0.938} & \\
\hline & 63 & 0.939 & & & 0.957 \\
\hline & 64 & 0.927 & & & \\
\hline & 65 & 0.918 & & & \\
\hline Internet security & 66 & 0.905 & 0.816 & 0.903 & 0.930 \\
\hline & 67 & 0.887 & & & \\
\hline & 68 & 0.958 & & & \\
\hline Legal barriers & 69 & 0.957 & 0.912 & 0.954 & 0.969 \\
\hline & 70 & 0.950 & & & \\
\hline
\end{tabular}

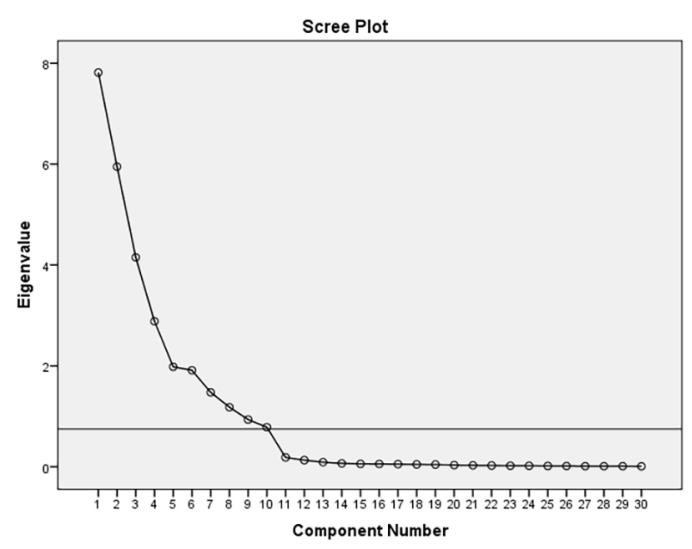

Figure 5. Scree plot of e-commerce barriers 
Table 6. Rotated component matrix of e-commerce adoption

\begin{tabular}{|l|c|c|c|c|c|}
\hline $\begin{array}{c}\text { Factor and } \\
\text { indicators }\end{array}$ & Items & $\begin{array}{c}\text { Factor } \\
\text { loading }\end{array}$ & AVE & VAVE & $\omega$ \\
\hline \multirow{3}{*}{$\begin{array}{l}\text { E-commerce } \\
\text { adoption }\end{array}$} & 71 & 0.945 & & & \\
\cline { 2 - 3 } & 72 & 0.930 & \multirow{2}{*}{0.760} & 0.872 & 0.905 \\
\cline { 2 - 3 } & 74 & 0.675 & & & \\
\hline
\end{tabular}

\subsection{Factors affecting e-customer loyalty}

Table 7 exhibits the rotated component matrix of the factors affecting e-customer loyalty. It was observed that the items loaded on 5 factors equally, with 3 items for each factor. Basically, the factor loadings of those items ranged from 0.721 to 0.911 . The validity and reliability were also accepted based on the AVE, $\sqrt{ }$ AVE, and McDonald's omega coefficient.

Table 7. Rotated component matrix of the factors affecting e-customer loyalty

\begin{tabular}{|c|c|c|c|c|c|}
\hline $\begin{array}{l}\text { Factors and } \\
\text { indicators }\end{array}$ & Items & $\begin{array}{l}\text { Factor } \\
\text { loading }\end{array}$ & AVE & $\sqrt{ }$ AVE & $\omega$ \\
\hline \multirow{3}{*}{$\begin{array}{l}\text { User } \\
\text { interface } \\
\text { quality }\end{array}$} & 75 & 0.841 & \multirow{3}{*}{0.689} & \multirow{3}{*}{0.830} & \multirow{3}{*}{0.865} \\
\hline & 76 & 0.891 & & & \\
\hline & 77 & 0.754 & & & \\
\hline \multirow{3}{*}{$\begin{array}{l}\text { Information } \\
\text { quality }\end{array}$} & 78 & 0.911 & \multirow{3}{*}{0.765} & \multirow{3}{*}{0.875} & \multirow{3}{*}{0.907} \\
\hline & 79 & 0.881 & & & \\
\hline & 80 & 0.831 & & & \\
\hline \multirow{3}{*}{$\begin{array}{l}\text { Customer } \\
\text { satisfaction }\end{array}$} & 81 & 0.799 & \multirow{3}{*}{0.702} & \multirow{3}{*}{0.838} & \multirow{3}{*}{0.876} \\
\hline & 82 & 0.852 & & & \\
\hline & 83 & 0.861 & & & \\
\hline \multirow{3}{*}{$\begin{array}{l}\text { Customer } \\
\text { trust }\end{array}$} & 84 & 0.898 & \multirow{3}{*}{0.734} & \multirow{3}{*}{0.857} & \multirow{3}{*}{0.892} \\
\hline & 85 & 0.753 & & & \\
\hline & 86 & 0.911 & & & \\
\hline \multirow{3}{*}{$\begin{array}{l}\text { E-commerce } \\
\text { ethics }\end{array}$} & 87 & 0.721 & \multirow{3}{*}{0.597} & \multirow{3}{*}{0.772} & \multirow{3}{*}{0.816} \\
\hline & 88 & 0.824 & & & \\
\hline & 89 & 0.769 & & & \\
\hline
\end{tabular}

\subsection{E-customer loyalty}

The rotated component matrix shown in Table 8 indicates that the items used to appraise e-customer loyalty loaded on the same factor, with the factor loadings ranging from 0.861 to 0.924 . Moreover, the convergent validity and discriminant validity were confirmed based on the AVE and $\sqrt{ }$ AVE values. As such, the values of McDonald's omega coefficient assured the reliability.

\subsection{Hypothesis testing}

Table 9 presents the results of hypotheses H1-H10, which examined 10 drivers of e-commerce. Suitably, the results specified that the hypothesized drivers were accepted from the sample members' viewpoint as significant e-commerce factors.
Table 8. Rotated component matrix of e-customer loyalty

\begin{tabular}{|c|c|c|c|c|c|}
\hline $\begin{array}{l}\text { Factor and } \\
\text { indicators }\end{array}$ & Items & $\begin{array}{l}\text { Factor } \\
\text { loading }\end{array}$ & AVE & $\sqrt{ }$ AVE & $\omega$ \\
\hline \multirow{7}{*}{$\begin{array}{l}\text { E-customer } \\
\text { loyalty }\end{array}$} & 90 & 0.924 & \multirow{7}{*}{0.806} & \multirow{7}{*}{0.898} & \multirow{7}{*}{0.967} \\
\hline & 91 & 0.861 & & & \\
\hline & 92 & 0.901 & & & \\
\hline & 93 & 0.875 & & & \\
\hline & 94 & 0.914 & & & \\
\hline & 95 & 0.889 & & & \\
\hline & 96 & 0.918 & & & \\
\hline
\end{tabular}

Table 9. Results of the hypotheses related to e-commerce drivers

\begin{tabular}{|c|c|c|c|c|c|}
\hline \multicolumn{3}{|c|}{ Default paths } & $\beta$ & C.R. & $\mathrm{P}$ \\
\hline $\begin{array}{l}\text { Top management } \\
\text { support (TMS) }\end{array}$ & $\rightarrow$ & \multirow{10}{*}{$\begin{array}{l}\text { E-com- } \\
\text { merce } \\
\text { adoption }\end{array}$} & 0.24 & 7.038 & 0.001 \\
\hline $\begin{array}{l}\text { Technical expertise } \\
\text { (TEX) }\end{array}$ & $\rightarrow$ & & 0.34 & 8.911 & 0.000 \\
\hline $\begin{array}{l}\text { E-commerce perceived } \\
\text { value }(\mathrm{ECPV})\end{array}$ & $\rightarrow$ & & 0.42 & 11.34 & 0.000 \\
\hline $\begin{array}{l}\text { Organizational culture } \\
\text { (ORC) }\end{array}$ & $\rightarrow$ & & 0.13 & 5.330 & 0.000 \\
\hline Customer trust (CST) & $\rightarrow$ & & 0.31 & 8.211 & 0.004 \\
\hline $\begin{array}{l}\text { Customer preferences } \\
\text { (CSP) }\end{array}$ & $\rightarrow$ & & 0.44 & 17.22 & 0.000 \\
\hline $\begin{array}{l}\text { E-commerce perceived } \\
\text { ease of use (ECPU) }\end{array}$ & $\rightarrow$ & & 0.21 & 6.894 & 0.002 \\
\hline $\begin{array}{l}\text { E-commerce cost } \\
\text { (ECC) }\end{array}$ & $\rightarrow$ & & 0.36 & 9.321 & 0.000 \\
\hline $\begin{array}{l}\text { Partner readiness } \\
\text { (PAR) }\end{array}$ & $\rightarrow$ & & 0.37 & 10.12 & 0.003 \\
\hline $\begin{array}{l}\text { Employee knowledge } \\
\text { and experience (EKN) }\end{array}$ & $\rightarrow$ & & 0.29 & 8.842 & 0.004 \\
\hline
\end{tabular}

The results in the table indicate that the most important factor in e-commerce adoption is customer preferences $(B=0.44, C R=17.22, P=0.000)$, followed by e-commerce perceived data $(\beta=0.42, C R=11.34, \mathrm{P}=0.000)$, partner readiness $(B=0.37, C R=10.12, P=0.003)$, e-commerce costs $(B=0.36, C R=9.32, P=0.000)$, technical expertise $(\beta=0.34, C R=8.91, P=0.000)$, customer trust $(B=0.31$, $\mathrm{CR}=8.21, \mathrm{P}=0.000)$, employee knowledge and experience $(~ B=0.29, C R=8.84, P=0.004)$, top management support $(B=0.24, C R=7.04, P=0.001)$, perceived ease of use $(B=0.21, C R=6.89, P=0.002)$, and organizational culture $(B=0.13, C R=5.33, P=0.000)$. Figure 6 depicts these results.

In terms of the e-commerce barrier hypotheses (H11$\mathrm{H} 20$ ), the results in Table 10 highlight 7 barriers of ecommerce adoption. That is, 7 hypotheses were supported.

It was observed that the connectivity cost is the most important barrier to e-commerce adoption $(B=0.46, C R=$ $8.18, P=0.000)$, followed by the technology cost $(B=0.43$, $\mathrm{CR}=7.94, \mathrm{P}=0.000)$, technical expertise $(B=0.44, \mathrm{CR}=$ $17.22, \mathrm{P}=0.000)$, employee technology knowledge $(B=$ 


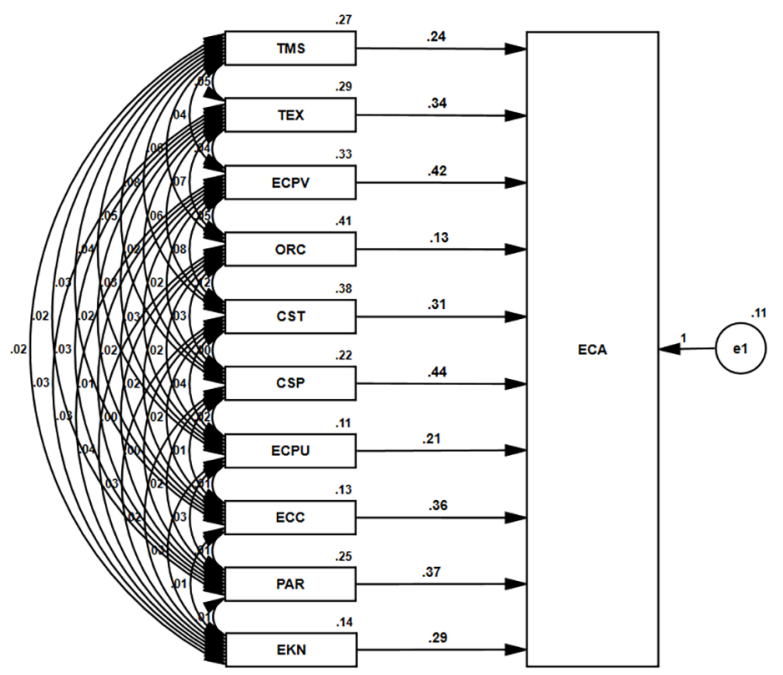

Figure 6. Results of the hypothesis testing (H1-H10)

$0.38, \mathrm{CR}=7.01, \mathrm{P}=0.001)$, internet security $(\beta=0.27$, $\mathrm{CR}=4.65, \mathrm{P}=0.001)$, telecommunications $(B=0.18$, $\mathrm{CR}=3.77, \mathrm{P}=0.004)$, and legal barriers $(B=0.11, \mathrm{CR}=$ $2.99, \mathrm{P}=0.000)$. Furthermore, the results, as illustrated in Figure 7 , showed that three variables were not found to exert significant effects on e-commerce adoption. Those factors are a lack of CEO's innovativeness (CEOI), lack of managerial time (MAT), and managerial e-commerce experience (MAE).

Concerning the factors affecting e-customer loyalty, as postulated in hypotheses $(\mathrm{H} 21-\mathrm{H} 25)$, the results reported in Table 11 and Figure 8 indicate that the hypotheses were

Table 10. Results of the hypotheses related to e-commerce drivers

\begin{tabular}{|c|c|c|c|c|c|}
\hline \multicolumn{3}{|c|}{ Default paths } & $ß$ & C.R. & $\mathrm{P}$ \\
\hline $\begin{array}{l}\text { Employee technology } \\
\text { knowledge (ETK) }\end{array}$ & $\rightarrow$ & \multirow{10}{*}{$\begin{array}{l}\text { E-com- } \\
\text { merce } \\
\text { adoption }\end{array}$} & 0.31 & 6.730 & 0.000 \\
\hline $\begin{array}{l}\text { Lack of CEO's } \\
\text { innovativeness } \\
\text { (CEOI) }\end{array}$ & $\rightarrow$ & & 0.09 & 0.781 & 0.271 \\
\hline $\begin{array}{l}\text { Lack of managerial } \\
\text { time (MAT) }\end{array}$ & $\rightarrow$ & & 0.07 & 0.131 & 0.314 \\
\hline $\begin{array}{l}\text { Managerial } \\
\text { e-commerce } \\
\text { experience (MAE) }\end{array}$ & $\rightarrow$ & & 0.02 & 1.424 & 0.083 \\
\hline $\begin{array}{l}\text { Telecommunications } \\
\text { (TEL) }\end{array}$ & $\rightarrow$ & & 0.18 & 3.771 & 0.004 \\
\hline $\begin{array}{l}\text { Connectivity cost } \\
\text { (CNC) }\end{array}$ & $\rightarrow$ & & 0.46 & 8.184 & 0.000 \\
\hline $\begin{array}{l}\text { Technical expertise } \\
\text { (TEE) }\end{array}$ & $\rightarrow$ & & 0.38 & 7.013 & 0.001 \\
\hline $\begin{array}{l}\text { Technology cost } \\
\text { (TCC) }\end{array}$ & $\rightarrow$ & & 0.43 & 7.941 & 0.000 \\
\hline $\begin{array}{l}\text { Internet security } \\
\text { (INS) }\end{array}$ & $\rightarrow$ & & 0.27 & 4.652 & 0.001 \\
\hline Legal barriers (LGB) & $\rightarrow$ & & 0.11 & 2.997 & 0.000 \\
\hline
\end{tabular}

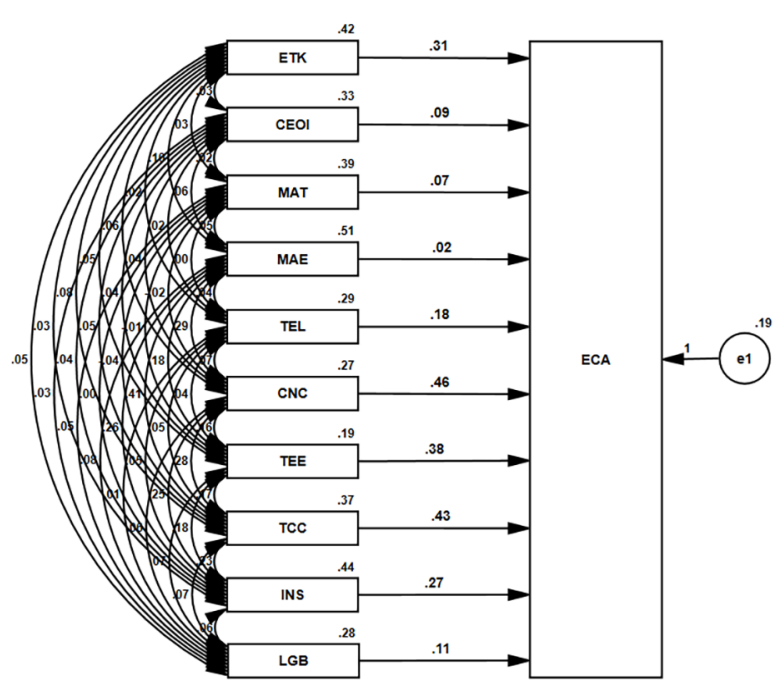

Figure 7. Results of the hypothesis testing (H11-H20)

accepted. Therefore, the factors examined in this study were found to exert significant effects on e-customer loyalty. In particular, e-commerce ethics was the most significant factor that affects e-customer loyalty $(\beta=0.38, \mathrm{CR}=$ 14.39, $\mathrm{P}=0.000$ ).

In the second order, information quality was found to exert a significant effect on e-customer loyalty $(B=0.33$, $\mathrm{CR}=13.25, \mathrm{P}=0.002)$, followed by customer trust $(B=$ $0.31, C R=12.36, P=0.000)$, user interface quality $(B=$ $0.29, \mathrm{CR}=11.02, \mathrm{P}=0.000)$, and customer satisfaction $(B=0.28, C R=10.89, P=0.001)$.

Table 11. Results of the factors affecting e-customer loyalty

\begin{tabular}{|c|c|c|c|c|c|}
\hline \multicolumn{3}{|c|}{ Default paths } & $B$ & C.R. & $\mathrm{P}$ \\
\hline $\begin{array}{l}\text { User interface } \\
\text { quality (UIQ) }\end{array}$ & $\rightarrow$ & \multirow{5}{*}{$\begin{array}{l}\text { E-customer } \\
\text { loyalty }\end{array}$} & 0.29 & 11.02 & 0.000 \\
\hline $\begin{array}{l}\text { Information quality } \\
\text { (INQ) }\end{array}$ & $\rightarrow$ & & 0.33 & 13.25 & 0.002 \\
\hline $\begin{array}{l}\text { Customer } \\
\text { satisfaction (CSS) }\end{array}$ & $\rightarrow$ & & 0.28 & 10.89 & 0.001 \\
\hline $\begin{array}{l}\text { Customer trust } \\
\text { (CUT) }\end{array}$ & $\rightarrow$ & & 0.31 & 12.36 & 0.000 \\
\hline $\begin{array}{l}\text { E-commerce ethics } \\
\text { (ETH) }\end{array}$ & $\rightarrow$ & & 0.38 & 14.39 & 0.000 \\
\hline
\end{tabular}

]

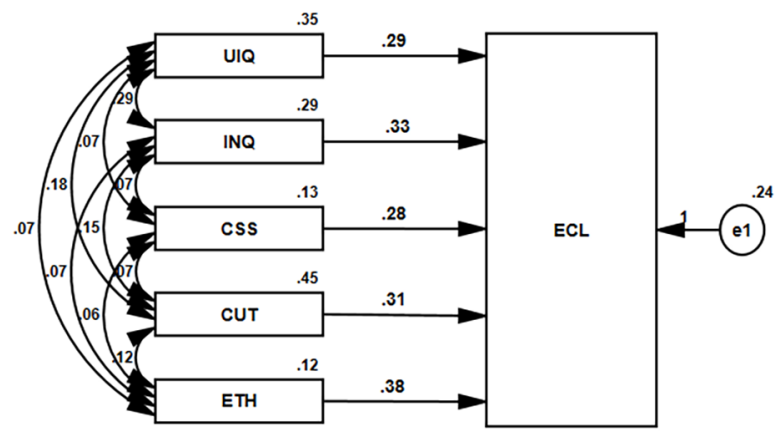

Figure 8. Results of hypothesis testing (H21-H25) 
The aim of this study was threefold: first, to explore the factors that affect e-commerce adoption; second, to examine the barriers that hinder the adoption of e-commerce in SMEs; and, third, to investigate the effect of some factors on e-customer loyalty. The results highlighted 10 drivers of e-commerce adoption, which were customer preferences, e-commerce perceived value, partner readiness, e-commerce cost, technical expertise, customer trust, employee knowledge and experience, top management support, perceived ease of use, and organizational culture.

In fact, the factors investigated in this study as drivers of e-commerce adoption were chosen from related works; therefore, numerous studies have found similar results to those of the current study. Awa et al. (2015a), referring to Tornatzky and Fleischer's (1990) e-commerce adoption framework, identified technological factors, organizational factors, and environmental factors as key drivers of e-commerce adoption. In agreement with them, the current study found that organizational factors, like the organizational culture, and environmental factors, such as partner readiness, are significant predictors of e-commerce adoption. The factors found in the current study echoed those of previous studies, including e-commerce perceived value (Ghobakhloo et al., 2011), employee knowledge of ecommerce (Van Huy et al., 2012), perceived ease of use of e-commerce applications, e-commerce relative advantage, e-commerce perceived compatibility, e-commerce security, top management support (Arshad et al., 2018), internet access (Ekanem \& Abiade, 2018), and perceived usefulness of e-commerce (Hussein et al., 2019). On the other hand, some scholars have found, in contrast to our results, that some factors, such as technology cost, have no influence on e-commerce adoption (Ghobakhloo et al., 2011).

Concerning the barriers to e-commerce adoption, the results highlighted seven barriers to e-commerce adoption, which are employee technology knowledge, telecommunications, connectivity cost, technical expertise, technology cost, internet security, and legal barriers. Differently, the CEO's innovativeness, managerial time, and managerial ecommerce experience have no influence on e-commerce as barriers to this construct. Prior works on e-commerce barriers have elucidated some barriers, like the absence of communication technology strategies (Lawrence \& Tar, 2010; Sabaityte et al., 2019), technical and legal barriers, a lack of internet security (Zaied, 2012), employees' low level of information technology, absence of innovativeness and managerial time, visible evaluation of e-commerce returns, cost (Scupola, 2009), and e-commerce perceived risk (Van Huy et al., 2012).

Regarding the factors that affect e-customer loyalty, the results showed that the endogenous construct is influenced by e-commerce ethics, information quality, customer trust, user interface quality, and customer satisfaction, respectively, which are the main predictors of e-customer loyalty. Srinivasan et al. (2002) found that e-customer loyalty is affected by characteristics such as customization, contact interactivity, cultivation, care, community, choice, and character. Additionally, Eid (2011) concluded that e-customer loyalty is strongly affected by customer satisfaction while being weakly affected by customer trust. Furthermore, Agag (2019) emphasized a positive effect of e-commerce ethics on e-customer loyalty. These results are similar to the results found in the current study.

On the basis of the current results, it was concluded that e-commerce adoption can be enhanced using several factors. An organization that intends to adopt e-commerce should consider several factors concerning the characteristics of the management of the organization, like top management support, employees' knowledge and experience, the technology cost and experience, and e-commerce perceived value, ease of use, and cost in addition to other factors, such as partners' readiness and organizational culture. A final important note is that customer trust and satisfaction are key factors of e-commerce adoption. Beyond that, a lack of these factors, in addition to other factors, such as internet security and legal regulations, are considered to be significant barriers to e-commerce adoption. Eventually, when adopting e-commerce, a focus on variables like customer trust and satisfaction, information quality, user interface quality, and e-commerce ethics is important to guide the organization to maintain customer loyalty in the context of e-commerce business.

\section{Limitations and recommendations}

Despite the literature review presented in this study, not all dimensions that have an effect on e-commerce adoption were considered. In a study by Hallikainen and Laukkanen (2018) on e-commerce trust using a sample consisting of customers from China and Finland, the national culture was found to play a significant role as a predictor of perceived trust in e-commerce stores. Therefore, it is recommended that more factors with a potential effect on e-commerce adoption should be examined. Kahraman et al. (2019) carried out a study on Turkish online consumers and found that their behaviours are affected by their demographic characteristics. In the current study, the demographic characteristics of local customers were not examined; therefore, it is suggested that future studies consider such factors. Agag's (2019) model of e-commerce's impact on customer repurchase intention and loyalty through relationship quality contains three control variables, which are firm age, firm size, and firm-customer relationship length. Firm characteristics were not studied in this paper. Therefore, future research on e-commerce effects should consider firm characteristics.

\section{Acknowledgements}

The author would like to thank all who participated in this research.

\section{Disclosure statement}

The author does not have any conflict of interest. 


\section{References}

Agag, G. (2019). E-commerce ethics and its impact on buyer repurchase intentions and loyalty: an empirical study of small and medium Egyptian businesses. Journal of Business Ethics, 154(5), 389-410. https://doi.org/10.1007/s10551-017-3452-3

Almousa, M. (2013). Barriers to e-commerce adoption: consumers' perspectives from a developing country. iBusiness, 5(2), 65-71. https://doi.org/10.4236/ib.2013.52008

Alsaad, A., Mohamad, R., \& Ismail, N. A. (2018). The contingent role of dependency in predicting the intention to adopt B2B E-commerce. Information Technology for Development, 25(4), 686-714. https://doi.org/10.1080/02681102.2018.1476830

Al-Tit, A. A., \& Nakhleh, H. (2014). The role of e-marketing in the development of internet user attitudes toward tourist sites in Saudi Arabia. Journal of Administrative and Economic Sciences, 7(2), 25-44. https://doi.org/10.12816/0009659

Al-Tit, A. A. (2016). The impact of lean supply chain on productivity of saudi manufacturing firms in Al-Qassim Region. Polish Journal of Management Studies, 14(1), 18-27. https://doi.org/10.17512/pjms.2016.14.1.02

Al-Tit, A., Omri, A., \& Bel Hadj, T. (2020). The driving factors of the social commerce intention of Saudi Arabia's online communities. International Journal of Engineering Business Management, 12, 1-8. https://doi.org/10.1177/1847979019899746

Al-Tit, A., Qmri, A., \& Euchi, J. (2019). Critical success factors of small and medium-sized enterprises in Saudi Arabia: insights from sustainability perspective. Administrative Sciences, 9(2), 32. https://doi.org/10.3390/admsci9020032

Arshad, Y., Chin, W. P., Yahaya, S. N., Nizam, N. Z., Masrom, N. R., \& Ibrahim, S. N. S. (2018). Small and medium enterprises' adoption for e-commerce in Malaysia tourism state. International Journal of Academic Research in Business and Social Sciences, 8(10), 1457-1557.

https://doi.org/10.6007/IJARBSS/v8-i10/5311

Awa, H. O., Ojiabo, O. U., \& Emecheta, B. C. (2015a). Integrating TAM, TPB and TOE frameworks and expanding their characteristic constructs for e-commerce adoption by SMEs. Journal of Science \& Technology Policy Management, 6(1), 76-94. https://doi.org/10.1108/JSTPM-04-2014-0012

Awa, H., Awara, N., \& Lebari, E. (2015b). Critical factors inhibiting Electronic Commerce (EC) adoption in Nigeria: A study of operators of SMEs. Journal of Science and Technology Policy Management, 6(2), 143-164. https://doi.org/10.1108/ JSTPM-07-2014-0033

Bharadwaj, P. N., \& Soni, R. G. (2007). E-commerce usage and perception of e-commerce issues among small firms: results and implications from an empirical study. Journal of Small Business Management, 45(4), 501-521. https://doi.org/10.1111/j.1540-627X.2007.00225.X

Chuang, T. T., Nakatani, K., Chen, J. C., \& Huang, I. L. (2007). Examining the impact of organisational and owner's characteristics on the extent of e-commerce adoption in SMEs. International Journal of Business and Systems Research, 1(1), 61-80. https://doi.org/10.1504/IJBSR.2007.014770

Corbitt, B. J., Thanasankit, T., \& Yi, H. (2003). Trust and e-commerce: a study of consumer perceptions. Electronic Commerce Research and Applications, 2(3), 203-215. https://doi.org/10.1016/S1567-4223(03)00024-3

Daniel, E., Wilson, H., \& Myers, A. (2002). Adoption of e-commerce by SMEs in the UK: towards a stage model. International Small Business Journal, 20(3), 253-270. https://doi.org/10.1177/0266242602203002
Davidavičienè, V., Davidavičius, S., \& Kaušinis, J. (2019). Consumer dissatisfaction structure - e-logistic perspective: Lithuania case. International Journal of Learning and Change, 11(3), 237-251. https://doi.org/10.1504/IJLC.2019.103328

Dunn, T. J., Baguley, T., \& Brunsden, V. (2014). From alpha to omega: A practical solution to the pervasive problem of internal consistency estimation. British Journal of Psychology, 105(3), 399-412. https://doi.org/10.1111/bjop.12046

Dwivedi, Y., Lal, B., \& Williams, M. (2009). Managing consumer adoption of broadband: examining drivers and barriers. Industrial Management \& Data Systems, 109(3), 357-369. https://doi.org/10.1108/02635570910939380

Eid, M. I. (2011). Determinants of e-commerce customer satisfaction, trust, and loyalty in Saudi Arabia. Journal of Electronic Commerce Research, 12(1), 78-93.

Ekanem, I., \& Abiade, G. E. (2018). Factors influencing the use of e-commerce by small enterprises in Nigeria. International Journal of ICT Research in Africa and the Middle East (IJICTRAME), 7(1), 37-53. https://doi.org/10.4018/IJICTRAME.2018010103

Feindt, S., Jeffcoate, J., \& Chappell, C. (2002). Identifying success factors for rapid growth in SME e-commerce. Small Business Economics, 19(1), 51-62. https://doi.org/10.1023/A:1016165825476

Gefen, D. (2000). E-commerce: The role of familiarity and trust. Omega, 28(6), 725-737. https://doi.org/10.1016/S0305-0483(00)00021-9

Ghobakhloo, M., Arias-Aranda, D., \& Benitez-Amado, J. (2011). Adoption of e-commerce applications in SMEs. Industrial Management \& Data Systems, 111(8), 1238-1269. https://doi.org/10.1108/02635571111170785

Gibbs, J., Kraemer, K. L., \& Dedrick, J. (2003). Environment and policy factors shaping global e-commerce diffusion: A crosscountry comparison. The Information Society, 19(1), 5-18. https://doi.org/10.1080/01972240309472

Green, S. B., \& Yang, Y. (2015). Evaluation of dimensionality in the assessment of internal consistency reliability: Coefficient alpha and omega coefficients. Educational Measurement: Issues and Practice, 34(4), 14-20. https://doi.org/10.1111/emip.12100

Hallikainen, H., \& Laukkanen, T. (2018). National culture and consumer trust in e-commerce. International Journal of Information Management, 38(1), 97-106. https://doi.org/10.1016/j.ijinfomgt.2017.07.002

Hua, N., Hight, S., Wei, W., Ozturk, A. B., Zhao, X., Nusair, K., \& DeFranco, A. (2019). The power of e-commerce: Does ecommerce enhance the impact of loyalty programs on hotel operating performance? International Journal of Contemporary Hospitality Management, 31(4), 1906-1923. https://doi.org/10.1108/IJCHM-02-2018-0168

Hussein, L. A., Baharudin, A. S., Jayaraman, K., \& Kiumarsi, S. (2019). B2B e-commerce technology factors with mediating effect perceived usefulness in Jordanian manufacturing SMES. Journal of Engineering Science and Technology, 14(1), 411-429.

Kabanda, S. K., \& Brown, I. (2015). E-commerce enablers and barriers in Tanzanian small and medium enterprises. The Electronic Journal of Information Systems in Developing Countries, 67(1), 1-24. https://doi.org/10.1002/j.1681-4835.2015.tb00485.x

Kahraman, N., Tunga, M. A., Ayvaz, S., \& Salman, Y. B. (2019). Understanding the purchase behaviour of Turkish consumers in $\mathrm{B} 2 \mathrm{C}$ e-commerce. International Journal of Intelligent Systems and Applications in Engineering, 7(1), 52-59. https://doi.org/10.18201/ijisae.2019151255 
Kassim, N., \& Abdullah, N. A. (2010). The effect of perceived service quality dimensions on customer satisfaction, trust, and loyalty in e-commerce settings A cross cultural analysis. Asia Pacific Journal of Marketing and Logistics, 22(3), 351-371. https://doi.org/10.1108/13555851011062269

Lawrence, J. E., \& Tar, U. A. (2010). Barriers to e-commerce in developing countries. Information, Society and Justice Journal, 3(1), 23-35.

Maydeu-Olivares, A., Kramp, U., García-Forero, C., GallardoPujol, D., \& Coffman, D. (2009). The effect of varying the number of response alternatives in rating scales: Experimental evidence from intra-individual effects. Behavior Research Methods, 41(2), 295-308.

https://doi.org/10.3758/BRM.41.2.295

McNeish, D. (2018). Thanks coefficient alpha, we'll take it from here. Psychological Methods, 23(3), 412-433. https://doi.org/10.1037/met0000144

Mueller, R. A. (2001). E-commerce and entrepreneurship in agricultural markets. American Journal of Agricultural Economics, 83(5), 1243-1249. https://doi.org/10.1111/0002-9092.00274

Mullane, J. V., Peters, M. H., \& Bullington, K. E. (2001). Entrepreneurial firms as suppliers in business-to-business e-commerce. Management Decision, 39(5), 388-393. https://doi.org/10.1108/00251740110395679

Osman, A., Wong, J. L., Bagge, C. L., Freedenthal, S., Gutierrez, P. M., \& Lozano, G. (2012). The depression anxiety stress Scales-21 (DASS-21): further examination of dimensions, scale reliability, and correlates. Journal of Clinical Psychology, 68(12), 1322-1338. https://doi.org/10.1002/jclp.21908

Rahayu, R. \& Day, J. (2015). Determinant factors of e-commerce adoption by SMEs in developing country: evidence from Indonesia. Procedia-Social and Behavioral Sciences, 195, 142150. https://doi.org/10.1016/j.sbspro.2015.06.423

Rahman, I., Rahmat, N., \& Nagapan, S. (2016). Structural relationships of success factors for Small Medium Enterprises (SME) contractors in PLS-SEM model. Engineering challenges for sustainable future - Zwawi. London: Taylor \& Francis group.

Raudeliūnienė J., et al. (2018). A study of success factors of women's leadership in e-commerce. Terra Economicus, 16(3), 131-149.
Sabaitytė J., et al. (2019). Decision tree modelling of e-consumers' preferences for internet marketing communication tools during browsing. E\&M Economics and Management, 22(1), 206-221. https://doi.org/10.15240/tul/001/2019-1-014

Scupola, A. (2009). SMEs' e-commerce adoption: perspectives from Denmark and Australia. Journal of Enterprise Information Management, 22(1/2),152-166. https://doi.org/10.1108/17410390910932803

Sebora, T. C., Lee, S. M., \& Sukasame, N. (2009). Critical success factors for e-commerce entrepreneurship: an empirical study of Thailand. Small Business Economics, 32(3), 303-316. https://doi.org/10.1007/s11187-007-9091-9

Senn, J. A. (2000). Business-to-business e-commerce. Information Systems Management, 17(2), 23-32. https://doi.org/10.1201/1078/43191.17.2.20000301/31224.3

Srinivasan, S. S., Anderson, R., \& Ponnavolu, K. (2002). Customer loyalty in e-commerce: an exploration of its antecedents and consequences. Journal of Retailing, 78(1), 41-50. https://doi.org/10.1016/S0022-4359(01)00065-3

Teo, T., \& Fan, X. (2013). Coefficient alpha and beyond: Issues and alternatives for educational research. The Asia-Pacific Education Researcher, 22(2), 209-213. https://doi.org/10.1007/s40299-013-0075-z

Tornatzky, L. G., \& Fleischer, M. (1990). The processes of technological innovation. Lexington, MA: Lexington Books.

Van Huy, L., Rowe, F., Truex, D., \& Huynh, M. Q. (2012). An empirical study of determinants of e-commerce adoption in SMEs in Vietnam: An economy in transition. Journal of Global Information Management (JGIM), 20(3), 23-54. https://doi.org/10.4018/jgim.2012070102

Wong, P. K. (2003). Global and national factors affecting e-commerce diffusion in Singapore. The Information Society, 19(1), 19-32. https://doi.org/10.1080/01972240309471

Wymer, S. A., \& Regan, E. A. (2005). Factors influencing e-commerce adoption and use by small and medium businesses. Electronic Markets, 15(4), 438-453. https://doi.org/10.1080/10196780500303151

Zaied, A. N. H. (2012). Barriers to e-commerce adoption in Egyptian SMEs. International Journal of Information Engineering and Electronic Business, 4(3), 9-18. https://doi.org/10.5815/ijieeb.2012.03.02 